\title{
DETERMINANTS OF YOUTH SMOKING-EVIDENCE FROM TURKEY
}

\author{
Yusuf Ziya Özcan, Ph.D., ${ }^{1, *}$ and \\ Kivilcim Metin Özcan, D.Phil. ${ }^{2}$ \\ ${ }^{1}$ Middle East Technical University, Ankara, Turkey \\ ${ }^{2}$ Bilkent University, Ankara, Turkey
}

\begin{abstract}
This paper investigates the determinants of smoking among middle- and high-school students in Ankara, Turkey. Data were collected from 4800 students in the second semester of the 1997-98 academic year to investigate substance use prevalence among young people. In addition to classical independent variables, factors which are not frequently used in the literature - such as school type, neighborhood, family religiosity, and factors reflecting the cultural background of the students - are included in the analysis. The results of binomial logistic regression offer evidence for the effects of school type, a smoking-related attitude, presence of a stepmother, father's use of alcohol, sister and brother who smoke, student's alcohol use, and participation in art activities.
\end{abstract}

Key Words: Youth smoking; Determinants of smoking; Turkey

*Corresponding author. Department of Sociology, Middle East Technical University, 06531 Ankara, Turkey. Fax: +90312210 1284;. E-mail: ozcan@metu.edu.tr

313 


\section{INTRODUCTION}

Today there are approximately 1.1 billion smokers in the world, which represents about one-third of the global population aged 15 years and over. Of these, 800 million are in developing countries (1). Consumption of tobacco has been declining in developed countries, a trend that has been counterbalanced by increasing consumption in developing countries, where $48 \%$ of men (700 million) and $7 \%$ of women (100 million) smoke, as opposed to $42 \%$ of men (200 million) and $24 \%$ of women (100 million) in developed countries (2).

Despite the overall decline in smoking among men in developed countries, the proportion of teenagers and young women who smoke increased in the 1990s (3). The overwhelming majority of smokers start before the age of 25 , often in childhood and adolescence. In developed countries, eight out of 10 begin in their teens. Jha and Chaloupka (1) estimate that the number of children and young people taking up smoking worldwide ranges from 14,000 to 15,000 per day, a rate increasing to 68,000 to 84,000 per day in middle- and low-income countries.

Two recent trends in cigarette smoking have important implications for developing countries. Smoking is traditionally associated with affluence. Though it used to be affluent men who smoked, now the opposite is true. Affluent men in developed countries are less likely to smoke. Similarly, it used to be educated men who smoked; nowadays it is the less-educated who tend to smoke more. Comparing average income and educational level between developed and developing countries, one could anticipate that smoking will remain a serious problem for developing countries (3), at least until they reach the level of developed countries.

Due to serious smoking-related medical problems and the possibly fatal results of smoking, the use of tobacco by young people has received considerable attention in the work of social scientists who were able to identify certain tendencies in youth smoking. Nearly all first use of tobacco occurs before high school graduation (4). Most young people who smoke get addicted to nicotine. Even if they want to quit, they find it difficult to do so. Tobacco is often the first drug used by young people who go on to use alcohol and illegal drugs (5). Those youngsters with poorer grades and lower self-image are most likely to begin using tobacco. Those who take up smoking believe that they can quit anytime. They also believe that the dangers of smoking are minimal when they are young and physically strong (2).

This paper provides evidence from a developing country, Turkey, where $42.4 \%$ of doctors smoke cigarettes (6). In addition to classical independent variables, this study employs school type, neighborhood, family 
religiosity, and factors reflecting the cultural background of the students which are not frequently used in the literature.

\section{LITERATURE ON YOUTH SMOKING}

Smoking is a dynamic, complex, multidimensional phenomenon which is bounded (culture-place-time-gender-religiosity etc.) and is most likely non-linear in its dimensions. Thus the selection of studies can never do adequate justice to the issues which need to be considered. The following review of selected studies is organized by factors used to explain youth smoking behavior.

\section{Studies Using Social Factors}

In a longitudinal analysis, Wang et al. (7) concluded that the smoking behavior of best friends was the only consistent and significant factor in predicting adolescent smoking progressing to the more advanced stages of acquisition. However, the ability of social factors to predict adolescent smoking was weak. Analyzing data from 933 children in grades 3 through 6 , Greenlund et al. (8) showed that having "ever smoked" at all was correlated with race, sex, and having a best friend or family member who smoked. The mother's smoking and the number of friends who smoke were also found to be associated with providing cigarettes (9).

Miller (10) showed that respondents living with both parents were significantly less likely to participate in alcohol, tobacco, and illicit drug use. Michell (11), studying 11- and 13-year-olds, stressed that different groups of pupils smoke for different reasons, related to pecking order and group membership. A study of 8900 minority teenagers in New Jersey (12) revealed that peer influence, self-initiation, and the relatives' smoking significantly contributed to the initiation of smoking. However, a longitudinal study (13) confirmed the influence of friends who smoked and positive attitudes and beliefs concerning smoking, but did not confirm the influence of parental and sibling smoking on adolescent smoking status.

A study of 1826 South Carolina public school students (14) showed that $43 \%$ of variation can be explained by age, race, involvement in activities with peer and family, peer smoking, family's smoking, and peers' acceptance of smoking. Those who reported low family and high peer involvement were more likely to smoke. Contrary to recent claims that girls smoke due to lack of self-esteem, Michell and Amos (15) showed that girls who smoke are more self-confident and socially skilled than their non-smoking peers. 
Smoking behavior was found to be closely linked to peer-group structure. Glendinning et al. (16) showed that support for teens was important in that an unsupportive home environment was associated with an increased likelihood of smoking. Smoking prevalence was raised where perceptions of poor support were combined with reports of less control.

A tree-wave Finnish study (17) indicated that smoking at age 20 was predicted by early smoking initiation, orientation towards peers, best friend's smoking at age 14, and mother's and father's smoking behavior. Again, socioeconomic status of the family was not a predictor of reported smoking behavior at 20 years of age. A British cohort study (18) following 6000 Derbyshire adolescents from 1974 to 1981 showed that boys and girls were more likely to smoke in 1981 if their fathers and mothers had smoked in 1974. However, after seven years, the influence of parental smoking was less on boys than girls, and mother's smoking appeared to influence both genders. Smoking siblings was also important in adult years.

In an eight-year longitudinal study in Los Angeles (19), peer smoking was shown to be a relatively weak predictor, while school influence (academic lifestyle orientation) appeared to be a strong negative predictor of young adult cigarette smoking. A 10-year follow-up of Oslo youths (20) indicated that smoking was strongly associated with the smoking behavior of friends and siblings when the teens were 11-14 years old. Interestingly enough, parental smoking and parents' educational level were not significant predictors of their offspring's smoking. Ten years later, mother's smoking was found to be the most important long-term predictor of daily smoking among young adults. These longitudinal studies suggest (although inconsistently) that family, friends, and schools affect smoking behavior, particularly during early adulthood.

Azevado et al. (21) found that teens over 12 years old were more likely to smoke if their parents had less than four years of education, their mother, siblings, or friends smoked, they had a low academic performance, and they habitually consumed coffee, alcohol, or illicit drugs. Abdelrahman et al. (22) showed that academic failure and peer use of substances have the strongest and greatest effects on current substance use (cigarettes, alcohol, and drugs). Epstein et al. (23) confirmed the influence of friends and family members, noting also that psychological characteristics such as advertising resistance skills, anti-smoking attitudes, and refusal skills lower the odds of smoking.

Despite their theoretical importance and numerous passing remarks, school and neighborhood do not seem to have attracted the attention of researchers. Allison et al. (24), studying 283 students from ages 13 to 18 from regular and special education classrooms in six schools, concluded that although peer and parental contexts were important predictors of substance use, school norms for drug use accounted for variance in adolescent 
use beyond that explained by peer and parental norms (see also reference 19). By using different data from 114 adolescents, they showed that neighborhood indices did not contribute to an understanding of adolescent substance use.

\section{Studies Using Psychological Factors}

Although much fewer in number, there are studies probing psychological factors in smoking. Canals et al. (25) found that $6.2 \%$ of the quantity of cigarettes used is accounted for by personality characteristics. Pederson et al. (26) described ever-smokers as more likely to have spending money, to work in a part-time job, to have missed school in the previous two months, to perceive themselves as below average or average in school, to have a mother, a father, and a sibling who smoke, and to have consumed alcohol. Eversmokers had more close friends who had tried smoking, spent more time with friends, scored higher on depression, rebelliousness, and social conformity scales, and had lower scores for social support. Although smokers were found to be more extroverted, tense, anxious, and antisocial than non-smokers, the strength of the relationship between personality and smoking is weak (27).

\section{Studies Using Other Factors}

A wide range of other factors, such as social activities (28), social bonds (29), perceptions $(12,30)$, attitudes $(8,31)$, image $(32,33)$, relatives (12), social class $(16,34)$, risk taking (35), step family (36), and imitation of movie stars (37) have been found to be related to youth smoking. Tyas and Pederson (38) have produced a longer list of factors associated with smoking.

Research conducted in Turkey also indicates conflicting results about the relative importance of the factors explaining youth smoking. Despite their differences in scope and methodology, they concur on the fact that the smoking rate is quite high in Turkey (39). According to a study of high-school students in 1999, 22.2\% were found to be smokers (40). Sezer et al. (41) found the smoking prevalence to be $41.2 \%$ among students. The rate among workers was $44.4 \%$ (42) and was $95 \%$ among bus drivers (43). Bilir et al. (39) report the smoking prevalence as $28.3 \%$ for high-school students, $3.5 \%$, for junior-high-school students, $50.8 \%$, for teachers, and $43.9 \%$ for doctors. Although their weights vary from study to study, Delikaya (40) stated that in order of importance, affectation, curiosity, family problems, friends' influence, and loneliness are the reasons given for taking up smoking. A list of selected studies on youth smoking in Turkey is presented in the Appendix. 


\section{METHOD}

\section{Sample and Data}

The data were collected from students of middle schools and high schools in Ankara, Turkey. Ankara is the capital and the second largest city in Turkey. Due to high inward migration, it also houses a sizeable number of people from rural backgrounds. The sample frame includes all middle schools and high schools in the city. In selecting schools, the neighborhoods where the schools are located were divided into three groups according to socioeconomic status. Statistics on type and number of schools at each level, and student populations were obtained by the Ministry of Education, and cross-checked by the schools themselves. Using information on type of school and student population, schools were selected randomly within each neighborhood group. The number of students to be included in the sample within each school was calculated proportionately to its population. The total number of students in the sample was 4800. After editing and excluding unusable cases, the sample size was reduced to 4767 , which is the largest sample drawn for smokingrelated research in Turkey. Sampling distribution of schools and students are given in table 1 .

The instrument used for data collection was a questionnaire with 43 closed-ended items. Since this study was initially a project written for the Police Academy, a group of Academy students were also involved in preparation, pre-testing of the questionnaire, and data entry. Before the fieldwork, the questionnaire, along with the research proposal, was sent to the Ministry of National Education to obtain permission to visit schools and administer a 35-minute questionnaire. Upon obtaining permission, pre-testing was done in a randomly selected secondary school with 60 students. In the light of the results, a few items were reformulated and the response categories of some questions were changed.

The final version of the questionnaire was administered to students in their classrooms where a teacher and one of the authors were present. After a brief introduction by the teacher, who then left the classroom, the author explained the nature of the survey by stressing two points; participation was voluntary and names were not required. The purpose was not to detect students who use substances but to understand the processes concerning initiation into and continued use of various substances among young people. None refused to participate but 33 students did not answer important questions on substance use and were excluded from the analysis. Fieldwork took place in the second term of the 1997-98 academic year and lasted six weeks. 


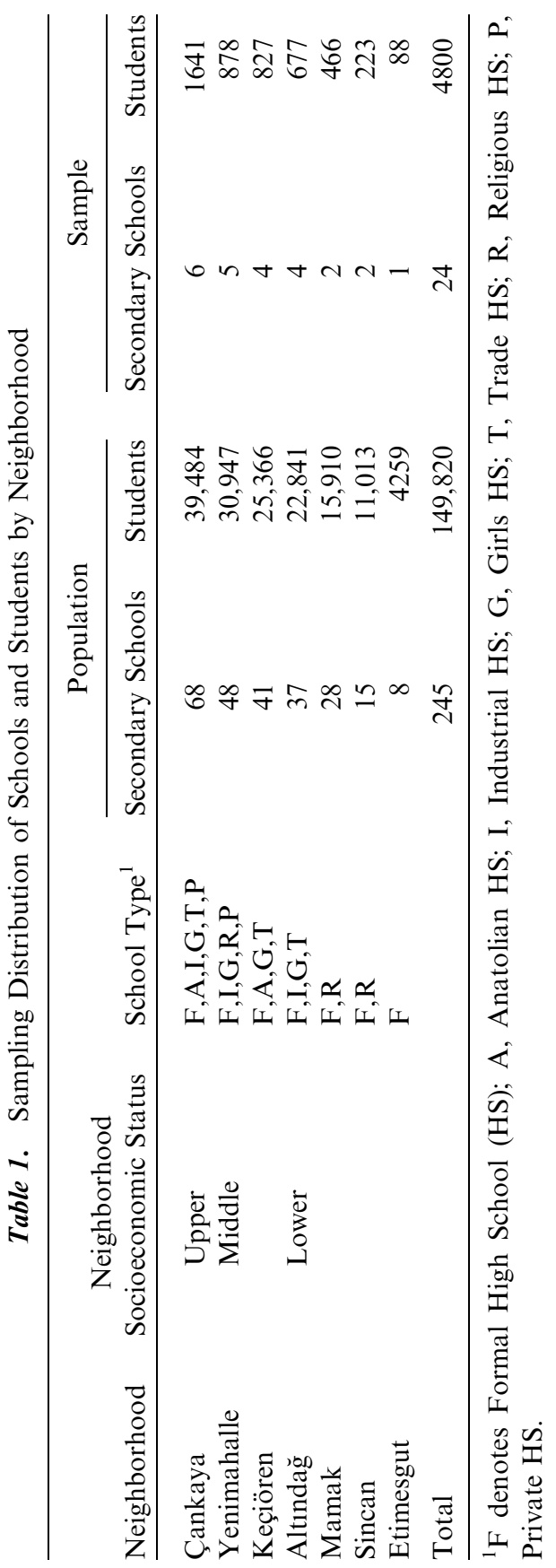


Table 2. Selected Characteristics of Students (\%)

\begin{tabular}{|c|c|c|}
\hline Variable & Non-smoker & Smoker \\
\hline \multicolumn{3}{|l|}{ Sex } \\
\hline Male & 52.2 & 56.3 \\
\hline Female & 47.8 & 43.7 \\
\hline \multicolumn{3}{|l|}{ School } \\
\hline Formal & 47.4 & 37.5 \\
\hline Anatolian & 10.8 & 7.1 \\
\hline Industrial & 10.9 & 13.0 \\
\hline Girls & 6.2 & 9.3 \\
\hline Trade & 4.9 & 0.5 \\
\hline Religious & 8.1 & 7.0 \\
\hline Private & 11.7 & 17.1 \\
\hline \multicolumn{3}{|l|}{ Neighborhood } \\
\hline Çankaya & 35.2 & 32.7 \\
\hline Yenimahalle & 17.6 & 21.4 \\
\hline Keçiören & 16.9 & 19.2 \\
\hline Altında $\breve{g}$ & 14.3 & 14.1 \\
\hline Mamak & 10.7 & 6.8 \\
\hline Sincan & 4.5 & 3.7 \\
\hline Etimesgut & 0.9 & 2.1 \\
\hline $\begin{array}{l}\text { Family intactne } \\
\text { Intact } \\
\text { Not intact }\end{array}$ & & \\
\hline \multicolumn{3}{|c|}{ Friend's substance use } \\
\hline No & 28.8 & 2.3 \\
\hline Yes & 71.2 & 97.7 \\
\hline \multicolumn{3}{|c|}{ Have step mother } \\
\hline No & 99.0 & 96.7 \\
\hline Yes & 1.0 & 3.3 \\
\hline \multicolumn{3}{|l|}{ Have step father } \\
\hline No & 99.4 & 98.2 \\
\hline Yes & 0.6 & 1.8 \\
\hline \multicolumn{3}{|c|}{ Language spoken at home } \\
\hline Turkish & 97.3 & 93.8 \\
\hline Other & 2.7 & 6.2 \\
\hline \multicolumn{3}{|c|}{ Mother's smoking } \\
\hline Non-smoker & 71.4 & 60.2 \\
\hline Smoker & 28.6 & 39.8 \\
\hline
\end{tabular}


YOUTH SMOKING IN TURKEY

Table 2. Continued

\begin{tabular}{|c|c|c|}
\hline$\underline{\text { Variable }}$ & Non-smoker & Smoker \\
\hline \multicolumn{3}{|c|}{ Mother's use of alcohol } \\
\hline Non-user & 92.7 & 87.0 \\
\hline User & 7.3 & 13.0 \\
\hline \multicolumn{3}{|l|}{ Father's smoking } \\
\hline Non-smoker & 43.4 & 32.8 \\
\hline Smoker & 56.6 & 67.2 \\
\hline \multicolumn{3}{|l|}{ Father's use of alcohol } \\
\hline Non-user & 75.6 & 64.7 \\
\hline User & 24.4 & 35.3 \\
\hline \multicolumn{3}{|l|}{ Sister-brother smoking } \\
\hline Non-smoker & 77.7 & 57.2 \\
\hline Smoker & 22.3 & 42.8 \\
\hline \multicolumn{3}{|c|}{ Sister-brother use of alcohol } \\
\hline Non-user & 88.3 & 75.6 \\
\hline User & 11.7 & 24.4 \\
\hline \multicolumn{3}{|l|}{ Do you use alcohol? } \\
\hline Never & 73.9 & 38.3 \\
\hline Tried once & 10.9 & 10.5 \\
\hline Used but quit & 0.9 & 2.5 \\
\hline Only when offered & 13.1 & 36.3 \\
\hline User & 1.2 & 12.4 \\
\hline \multicolumn{3}{|l|}{ Region of birth } \\
\hline Aegean-Trace & 4.4 & 3.7 \\
\hline Mediterranean & 1.6 & 1.9 \\
\hline Central A & 8.7 & 82.0 \\
\hline Black Sea & 3.7 & 2.0 \\
\hline East-S. East & 6.4 & 6.7 \\
\hline Foreign born & 2.2 & 3.6 \\
\hline \multicolumn{3}{|c|}{ Sell cigarettes to people under 18} \\
\hline Agree & 88.3 & 59.6 \\
\hline Disagree & 11.7 & 40.4 \\
\hline
\end{tabular}

The primary reason for collecting the data was to assess the degree of substance use prevalence and the reasons for such use among middle-and high-school students. Table 2 summarizes selected characteristics of the sampled students. 


\section{Determinants of Smoking}

The dependent variable is smoking status, which taps the degree of addiction to smoking. The original five-category variable, "never smoked," "tried once," "smoked and quit," "smokes when offered," and "smoker" was transformed into a binomial by combining the first three as nonsmokers (includes ex-smokers) and the last two categories into a smoker category in order to have mutually-exclusive categories.

The independent variables can be grouped under five subtitles: personal characteristics, attitudes toward smoking-related issues, family, school, and neighborhood environment. The personal characteristics measured are sex, age, region of birth, academic failure in school, participation in art studies, the amount of pocket money, information about drugs, having friends who offer cigarettes, ever punished in school, having friends who smoke, type of place where primary education completed, type of place where junior-high-school education completed, use of alcohol, response to cigarette offer, and age started to smoke.

The region of birth and place where primary school and junior high school were completed are important in that they reflect the background of the students. Receiving punishment and academic performance are included in the analysis to test the claim that smokers are not as successful as non-smokers academically and tend to commit more "deviant" acts (44).

The attitude variables included in the dataset are reaction to selling cigarettes to youngsters, following strict policies to curb smoking, and the media's effect in encouraging and discouraging students.

Family environment is tapped by family intactness, living or not living with family, having a stepmother, having a stepfather, mother's use of tobacco, father's use of tobacco, sister and brother's use of tobacco, mother's use of alcohol, father's use of alcohol, sister and brother's use of alcohol, working status of mother, working status of father, family control over teenager, family income (measured by family consumption), religiosity of family (self-reported), language spoken in the family, family's knowledge of student's smoking.

Family intactness and living together with family are included since they were found to be important in the literature for explaining both the initiation and maintenance of smoking $(11,23,38)$. Religiosity and

the language of the family are two variables measuring the possible effects of religion and ethnic identification on smoking. The use of cigarettes and alcohol by family members are included in order to study if they have any effect on the smoking status of students. Family control is included to test if authoritative parenting has any positive or 
negative effect on students' smoking habits. Having brothers or sisters who smoke and use alcohol at home may set up a role model for the adolescent.

School environment is measured by type of school. Students attend one of the seven different schools: formal, Anatolian, industry vocational, girls' vocational, commercial (trade), Imam Hatip (religious), and private. Except for the private schools, all are free. Formal high schools are regular high schools whose graduates are targeted to enter university. Anatolian high schools are special state schools for successful students. Industry, girls', trade, and religious high schools are vocational schools whose graduates can start working after graduation. Although they are all secondary-level schools, each follow different educational objectives and exercise a different set of rules, which attracts a different body of students from various backgrounds. There are also marked differences in their academic success. Measured by the percent of graduates who pass the National University Entrance Exam, Anatolian high schools are the most successful, followed by private, formal, and vocational schools (industry, girls', trade, and religious). Neighborhood is used to tap the socioeconomic status of the area where the students live. It seems that neighborhoods are as important as schools, if not more so, for creating an environment in which adolescents go through tumultuous periods of personality development. Actually, students form some of their friendships in their own neighborhoods, which tend to continue in school. Moreover, the schools located in those neighborhoods benefit or suffer to varying degrees from the general atmosphere of the neighborhood.

\section{RESULTS}

\section{Empirical Analysis}

Turkey, like many developing countries, is notorious for having a high smoker rate. According to the WHO study conducted between 1990 and 1992, it ranked 25 among 100 nations measured by number of cigarettes smoked per person (45). In the present sample, $24 \%$ of the students are smokers, with little difference by sex $(22.4 \%$ of the females and $25.4 \%$ of the males are smokers). Table 3 presents the results of the crosstabulations of categorical independent variables with the smoking status of the students. All variables seem to be related to the smoking status of the students with the exception of mother's and father's working status, place where students attended primary school and junior high school, having 
Table 3. Existence of Relationship Between Smoking Status (SMOKE) and Independent Variables

\begin{tabular}{|c|c|c|c|}
\hline$\underline{\text { Independent Variables }}$ & $\chi^{2}$ & df & $p$ \\
\hline Sex of the student (SEX) & 5.9 & 1 & .015 \\
\hline Neighborhood (NEIGHBORHOOD) & 35.4 & 6 & .001 \\
\hline School type (SCHOOLTYPE) & 85.2 & 6 & .001 \\
\hline Living with parents (PARENTS) & 21.4 & 1 & .001 \\
\hline Family control (FAMCONTR) & 29.2 & 1 & .001 \\
\hline Failure in school (FAILURE) & 48.9 & 1 & .001 \\
\hline Punishment in school (PUNISH) & 69.5 & 1 & .001 \\
\hline Mother's smoking (MOSMOKE) & 49.3 & 1 & .001 \\
\hline Mother's use of alcohol (MOALC) & 34.8 & 1 & .001 \\
\hline Father's smoking (FASMOKE) & 38.1 & 1 & .001 \\
\hline Father's use of alcohol (FAALC) & 49.8 & 1 & .001 \\
\hline Sister-brother smoking (SIBRSMOKE) & 168.1 & 1 & .001 \\
\hline Sister-brother use of alcohol (SIBRALC) & 103.2 & 1 & .001 \\
\hline \multicolumn{4}{|l|}{ Attitudes toward selling cigarettes } \\
\hline to youngsters (SELLCIG) & 468.3 & 1 & .001 \\
\hline Having a stepmother (STEPMO) & 29.0 & 1 & .001 \\
\hline Having a stepfather (STEPFA) & 13.9 & 1 & .001 \\
\hline Mother's working status (MOWORK) & 2.5 & 2 & .282 \\
\hline Father's working status (FAWORK) & 1.4 & 2 & .492 \\
\hline \multicolumn{4}{|l|}{ Place where primary school attended } \\
\hline Place where JHS attended (PLACEJHS) & 3.8 & 2 & .149 \\
\hline \multicolumn{4}{|l|}{ Language spoken in the family } \\
\hline (FAMLANGUAGE) & 29.2 & 1 & .001 \\
\hline Student's use of alcohol (ALCOHOL) & 715.1 & 4 & .001 \\
\hline \multicolumn{4}{|l|}{ Response when cigarette offered } \\
\hline (WHNOFFERED) & 654.3 & 1 & .001 \\
\hline Having friend who offered cigarette (OFFER) & 821.0 & 1 & .001 \\
\hline \multicolumn{4}{|l|}{ Attitudes about strict control of smoking } \\
\hline (POLCONT) & 5.5 & 1 & .019 \\
\hline Having information about substances (INFO) & 1.3 & 1 & .259 \\
\hline \multicolumn{4}{|l|}{ Attitudes towards media's role on smoking } \\
\hline (MEDIA) & 1.9 & 2 & .380 \\
\hline Region of birth (BREGION) & 14.7 & 5 & .011 \\
\hline Participation in art work (ART) & 7.8 & 1 & .005 \\
\hline Having friends who smoke (FRIUSE) & 349.94 & 1 & .001 \\
\hline Living or not living with family (WHOMLIVE) & 22.15 & 3 & .001 \\
\hline Family knows child's smoking (FAMKNOW) & 3.44 & 1 & .063 \\
\hline
\end{tabular}


Table 4. Differences Between Smokers and Non-smokers

\begin{tabular}{lcrc}
\hline Independent Variable & $t$-Value & df & $p$ \\
\hline Age (AGE) & 11.4 & 4722 & .001 \\
Family consumption (FAMCONSUMP) & 4.85 & 3515 & .001 \\
Pocket money (POCKET) & 7.24 & 41,172 & .001 \\
Participation in art works (ARTS) & 1.4 & 4729 & .155 \\
Smoking age (AGESMOKE) & 1.84 & 2291 & .065 \\
Family religiosity (FAMRELIG) & 1.8 & 4526 & .077 \\
\hline
\end{tabular}

information about substances, and attitude towards the media's role in smoking.

For the interval independent variables, a $t$-test is used to determine if the differences between smokers and non-smokers are significant. Table 4 presents the results. Mean tests indicate that there are significant differences between smokers and non-smokers, which are not homogenous, with respect to age, family consumption and pocket money, and not significantly different with respect to participation in art studies, smoking age, and family religiosity. Variables that do not have significant relationships with the smoking status of students or do not indicate a significant difference by smoking status were eliminated from the analysis.

\section{Binomial Logistic Modelling}

The model assumes direct influence of all independent variables on smoking status. In short, it is:

$$
y=a+\beta_{i} x_{i}+\mathrm{e}_{i}
$$

where $\beta_{i}$ represents logistic regression (LR) coefficients, $x_{i}$ represents independent variables, and $\mathrm{e}_{i}$ is used for the error term. The results of the maximum likelihood estimation (MLE) are given in table 5. The conditional forward method is used and the significance level for regression coefficients is set to .10 (46). The independent variables in the model represent five different effects: neighborhood, school, family environment, personal characteristics, and attitudes toward smoking-related issues and policies. The dependent variable, smoking status, is a binomial variable, 0 representing non-smokers and 1 representing smokers. Non-smokers serve as a reference category (47). 
Table 5. Results of Binomial Logistic Regression

\begin{tabular}{|c|c|c|c|c|c|c|}
\hline Variables & B & S.E. & Wald & $\mathrm{df}$ & Sig. & $\operatorname{Exp}(B)$ \\
\hline AGE & .093 & .070 & 1.776 & 1 & .183 & 1.098 \\
\hline FAMCONSUMP & .000 & .000 & .518 & 1 & .472 & 1.000 \\
\hline POCKET & .000 & .000 & 1.168 & 1 & .280 & 1.000 \\
\hline NEIGHBORHOOD & & & 5.508 & 6 & .481 & \\
\hline Çankaya & -1.061 & .662 & 2.568 & 1 & .109 & .346 \\
\hline Yenimahalle & -1.071 & .676 & 2.508 & 1 & .113 & .343 \\
\hline Keçiören & -1.265 & .669 & 3.576 & 1 & .059 & .282 \\
\hline Altında $\breve{g}$ & -1.344 & .676 & 3.951 & 1 & .047 & .261 \\
\hline Mamak & -1.128 & .685 & 2.713 & 1 & .100 & .324 \\
\hline Sincan & -.966 & .724 & 1.783 & 1 & .182 & .381 \\
\hline SCHOOLTYPE & & & 35.978 & 6 & .000 & \\
\hline Formal & .228 & .254 & .809 & 1 & .368 & 1.256 \\
\hline Anatolian & -.964 & .321 & 9.011 & 1 & .003 & .381 \\
\hline Industry Voc. & .489 & .285 & 2.944 & 1 & .086 & 1.630 \\
\hline Girl Voc. & .861 & .350 & 6.043 & 1 & .014 & 2.366 \\
\hline Commercial & .988 & .357 & 7.660 & 1 & .006 & 2.685 \\
\hline Religious & .063 & .342 & .034 & 1 & .853 & 1.065 \\
\hline $\operatorname{SEX}(1)$ & .162 & .160 & 1.030 & 1 & .310 & 1.176 \\
\hline SELLCIG(1) & 1.166 & .158 & 54.629 & 1 & .000 & 3.208 \\
\hline PARENTS(1) & .508 & .461 & 1.212 & 1 & .271 & 1.662 \\
\hline STEPMO(1) & -2.030 & .878 & 5.343 & 1 & .021 & .131 \\
\hline STEPFA(1) & .394 & .994 & .157 & 1 & .692 & 1.482 \\
\hline FAMLANGUA(1) & .260 & .338 & .594 & 1 & .441 & 1.297 \\
\hline FAMCONTR(1) & -.089 & .164 & .297 & 1 & .586 & .914 \\
\hline FAILURE(1) & .199 & .203 & .964 & 1 & .326 & 1.220 \\
\hline PUNISH(1) & -.335 & .306 & 1.201 & 1 & .273 & .715 \\
\hline MOSMOKE(1) & -.029 & .154 & .035 & 1 & .852 & .972 \\
\hline MOALC(1) & .228 & .252 & .815 & 1 & .367 & 1.256 \\
\hline FASMOKE(1) & -.226 & .141 & 2.549 & 1 & .110 & .798 \\
\hline FAALC(1) & .395 & .169 & 5.458 & 1 & .019 & 1.484 \\
\hline SIBRSMOKE(1) & -.543 & .166 & 10.653 & 1 & .001 & .581 \\
\hline SIBRALC(1) & .000 & .209 & .000 & 1 & 1.000 & 1.000 \\
\hline ALCOHOL & & & 31.095 & 4 & .000 & \\
\hline Never & -1.962 & .353 & 30.951 & 1 & .000 & .141 \\
\hline Tried once & -1.783 & .375 & 22.586 & 1 & .000 & .168 \\
\hline Used and quit & -1.526 & .546 & 7.800 & 1 & .005 & .217 \\
\hline Only when offered & -1.617 & .333 & 23.575 & 1 & .000 & .198 \\
\hline WHNOFFERED(1) & -3.042 & .227 & 180.277 & 1 & .000 & .048 \\
\hline OFFER(1) & .581 & 1.220 & .227 & 1 & .634 & 1.787 \\
\hline POLCONT(1) & -.047 & .207 & .052 & 1 & .820 & .954 \\
\hline
\end{tabular}


Table 5. Continued

\begin{tabular}{lcccccr}
\hline Variables & B & S.E. & Wald & df & Sig. & Exp(B) \\
\hline BREGION & & & 4.516 & 5 & .478 & \\
$\quad$ Aegean & -.391 & .507 & .592 & 1 & .442 & .677 \\
$\quad$ Mediterranean & -.813 & .626 & 1.685 & 1 & .194 & .443 \\
$\quad$ Central & -.606 & .397 & 2.329 & 1 & .127 & .545 \\
$\quad$ Black Sea & -.954 & .564 & 2.863 & 1 & .091 & .385 \\
$\quad$ East-Southeast & -.312 & .483 & .417 & 1 & .518 & .732 \\
ARTS(1) & .323 & .142 & 5.181 & 1 & .023 & 1.382 \\
FRIUSE & 5.244 & 6.272 & 0.699 & 1 & .403 & 189.363 \\
Constant & 2.657 & 1.989 & 1.784 & 1 & .182 & 14.246 \\
\hline
\end{tabular}

Nagelkerke $R^{2} .470$. Cox and Snell $R^{2} .348$. McFadden .540. Adjusted count $R^{2} .420$.

\section{Neighborhood Effect}

Students living in all neighborhoods seem to have had a lower chance of becoming smokers compared with students living in Etimesgut (default), a lower-class neighborhood. However, the coefficients of only three neighborhoods are significant and deserve interpretation. Living in Keçiören, a middle-class neighborhood, or Altındağ and Mamak, lower-class neighborhoods, lessens the chance of students becoming smokers by $.28, .26$, and .32 times respectively compared to students living in Etimesgut. This is the expected finding. However, this would have been further confirmed had the regression coefficients of the upper- and middle-class neighborhoods, Çankaya and Yenimahalle, been significant and indicated much lower probabilities for becoming a smoker. These findings lend partial support to the neighborhood effect on smoking.

\section{School Effect}

As formulated at the outset, school type seems to have an effect on the smoking behavior of students in general. However, this effect is evident in all schools except regular and religious schools. Being a student in the most academically successful schools, Anatolian high schools, decreases the chance of becoming a smoker by .38 times, compared to private high school students. Being a student in industrial, girls', and commercial high schools increases the likelihood of becoming a smoker by 1.6, 2.4 and 2.7 times respectively compared to students of private high schools. These findings confirm the school-effect hypothesis. 


\section{Family Environment}

Only having a stepmother, father's use of alcohol, and sister's and brother's smoking seem to influence students' smoking status. Contrary to expectations, having a stepmother seems to lessen a student's chance of becoming a smoker by .13 times as compared to those who do not have a stepmother. An alcohol-user father increases his children's chance of becoming smokers by 1.48 times more than those whose fathers do not use alcohol. Again, contrary to expectations, having smoker sisters and brothers lessens the chance of becoming a smoker compared to those who do not have smoking sisters or brothers. Findings concerning the family environment do not seem to be in agreement with the disproportional importance attributed to family-related factors in previous studies on youth smoking. Factors that are expected to be influential, such as family intactness, living with parents, family control over children, and family income (tapped with family consumption), do not seem to have any effect on youth smoking in Turkey. Moreover, some of the factors that are significant have the reverse effect, as is the case for stepmother and smoking sisters and brothers. The only familyrelated factor that agrees with the general belief is the effect of an alcohol-user father.

\section{Personal Characteristics}

Among the variables measuring personal characteristics, only response to an offer of cigarettes, student's alcohol use, and participation in art activities seem to have a significant relationship with smoking status. Since the variable "response to cigarette offers" has a very high Wald statistic value, it will not be interpreted. Participating in art activities increases the student's chance of becoming a smoker by 1.38 times, compared to non-active students. Compared to alcohol-user students (default), students who "never use alcohol," "tried once," "used but quit," and "use only when offered" are less likely to become smokers. In fact, students who used alcohol and quit have .22 times less chance of becoming cigarette smokers. This likelihood is .14 for never users, .17 times for quitters, and .20 for those who use alcohol only when offered.

Findings in this section indicate less agreement with earlier findings. The only satisfactory agreement concerns the use of alcohol by the students. Hypotheses claiming the relationship of smoking status to academic success (failure), deviant acts in school, the amount of pocket money, knowledge about the danger of using substances, and sex do not seem to be confirmed in Turkey. Among the attitude variables, responses to selling cigarettes 
to adolescents under 18 years of age seems to be significantly related to smoking status. Interestingly, those students who oppose the ban on selling cigarettes to youngsters have a 3.2 greater chance of becoming smokers than those who favor the ban.

To assess the fit of the model, three widely known measures are presented, all of which have certain limitations and difficulties in interpretation (47). These are Nagelkerke (48), Cox and Snell (49), and McFadden (50) (also called likelihood ratio index). Moreover, the adjusted count $R^{2}$ is calculated to be .42 . Based on the adjusted count $R^{2}$, it is safe to conclude that the independent variables used in the model reduce the error in prediction by $42 \%$. The model used classifies $77 \%$ of the cases correctly.

\section{DISCUSSION}

This study has some limitations in that it uses cross-sectional data, which do not allow one to establish order of precedence among variables, and do not include some variables that mediate in relations between smoking and other independent variables. Despite these limitations, the results obtained here prove once more that predicting youth smoking behavior is a challenging task which is, in part, due to the use of linear techniques to capture non-linear relations. Even the most likely variables, such as parents' smoking, intactness of the family, receiving offers to smoke cigarettes, and having smoking friends, did not seem to influence student smoking. The influence of the important variables, such as having a stepmother, and having smoking sisters and brothers was the opposite.

Schools and neighborhoods, to a lesser extent, also seem to have an effect on smoking. This is, to a large extent, cultural in Turkey. Anatolian, religious, and formal schools are different in that Anatolian high schools attract the most successful students who are achievement-oriented and receive full support from their families. Religious schools exercise spiritual control over students, which is reinforced by their religious families, by stressing Islamic principles that they should not harm the body given by God. In formal high schools, there is again strict control over smoking, whereas students of vocational schools come from mostly lower-class families who cannot afford to send their children to university and prefer them to start working after secondary school. These children work during school breaks as apprentices or on the streets to contribute to the family budget. Making money at earlier ages and working in environments that encourage smoking can initiate smoking at earlier ages, which they maintain afterwards. Similarly, neighborhoods vary considerably in their quality of life. In general, families of poor neighborhoods provide 
inconsistent support to their children, have low educational aspirations, lack closeness and involvement in the children's activities, exert weak control and discipline, approve of substance use explicitly or implicitly and resort to it on a regular basis, and abuse their children emotionally or physically. However, poor neighborhoods also house conservative and religious people who not only oppose any substance use but also cannot afford to buy them. This is why students from some poor neighborhoods (Sincan and Mamak) are less likely to smoke. These findings imply that neighborhood, family well-being, religiosity and school type are interrelated and should be included in further research to be conducted in developing countries.

\section{APPENDIX}

Selected Studies on Youth Smoking in Turkey

\begin{tabular}{|c|c|c|c|c|}
\hline Author & Sample & Techniques & Result & $\begin{array}{l}\text { General- } \\
\text { izability }\end{array}$ \\
\hline $\begin{array}{l}\text { Karavuş } \\
\text { et. al. } \\
1993(51)\end{array}$ & $\begin{array}{l}\text { Senior high-school stu- } \\
\text { dents in Istanbul neigh- } \\
\text { borhood } N=224\end{array}$ & $\begin{array}{l}\text { Correlation } \\
t \text {-test, ANOVA, } \\
\text { cross-tabulation }\end{array}$ & $\begin{array}{l}\text { Stress was found to be } \\
\text { unrelated to mother's } \\
\text { and father's educa- } \\
\text { tional level }\end{array}$ & No \\
\hline $\begin{array}{l}\text { Kiyak } \\
\text { and } \\
\text { Dayığlu, } \\
1988 \text { (52) }\end{array}$ & $\begin{array}{l}\text { High-school students in } \\
\text { Istanbul neighborhood, } \\
N=1000\end{array}$ & $\begin{array}{l}\text { Frequencies and } \\
\text { cross-tabulation }\end{array}$ & $\begin{array}{l}\text { The most important } \\
\text { factor for smoking } \\
\text { was curiosity and atti- } \\
\text { tude of age group }\end{array}$ & No \\
\hline $\begin{array}{l}\text { Delikaya, } \\
1999(40)\end{array}$ & $\begin{array}{l}\text { Students from five high } \\
\text { schools in Ankara, } \\
N=501\end{array}$ & $\begin{array}{l}\text { Frequencies, } \\
\text { cross-tabulation }\end{array}$ & $\begin{array}{l}\text { Reasons for smoking } \\
\text { were found to be } \\
\text { showing off, curiosity, } \\
\text { and family problems }\end{array}$ & No \\
\hline $\begin{array}{l}\text { Saltık } \\
\text { et al. } \\
1990(53)\end{array}$ & $\begin{array}{l}\text { Middle- and high-school } \\
\text { students in Edirne, } \\
N=1362\end{array}$ & $\begin{array}{l}\text { Frequencies, } \\
\text { cross-tabulations } \\
\text { and graphs }\end{array}$ & $\begin{array}{l}\text { Reasons for smoking } \\
\text { were found to be } \\
\text { friends, showing off, } \\
\text { and curiosity }\end{array}$ & No \\
\hline $\begin{array}{l}\text { Güraksin } \\
\text { et al. } \\
1994(54)\end{array}$ & $\begin{array}{l}\text { Junior-high and high- } \\
\text { school students in } \\
\text { Erzurum, } N=1855\end{array}$ & Cross-tabulation & $\begin{array}{l}\text { First smoking occurs } \\
\text { between ages 12-13 } \\
\text { which increases as } \\
\text { age increases. Smoker } \\
\text { in the family and } \\
\text { smoker friend incre- } \\
\text { ase the chance of } \\
\text { being smoker }\end{array}$ & No \\
\hline $\begin{array}{l}\text { Sezer } \\
\text { et al. } \\
1989(55)\end{array}$ & $\begin{array}{l}\text { High-school and equi- } \\
\text { valent school students in } \\
\text { Elazı } \breve{g}, N=800\end{array}$ & Cross-tabulation & $\begin{array}{l}\text { Percentage of smokers } \\
\text { was } 41.2 \text { for men and } \\
9.5 \text { for women }\end{array}$ & No \\
\hline
\end{tabular}




\section{ACKNOWLEDGMENTS}

The authors thank The Ministry of National Education for the permission granted for data collection. We would also like to thank the group of Police Academy students who participated in various phases of the study. Foremost, we are grateful to two anonymous referees who contributed immensely to the quality of this paper.

\section{REFERENCES}

1. Jha, P.; Chaloupka, F.J. Curbing the Epidemic: Governments and the Economics of Tobacco Control; The World Bank: Washington D.C., 1999.

2. WHO. WHO Information: Fact Sheet No: 154. http://www.who.int/ inffs/en/fact154.html (1998).

3. Yach, D.; Shisana, O. Preface. In Smoking and Women's Health: "Les Liaisons Dangereuses"; Flowers, M.K., Bodkin, M., Eds.; Global Alliance for Women's Health: New York, 1999.

4. U.S. Department of Health and Human Services. Preventing Tobacco Use Among Young People: A Report of the Surgeon General. http:// www.cdc.gov/nccdphp/osh/94oshaag.htm (1994).

5. SAMHSA 1995 National Household Survey on Drug Abuse. http:// www.cdc.gov/nccdphp/osh/samhsa.htm

6. Aşut, Ö. Türkiye'de Hekimlerin Sigara Alışkanlığı (Cigarette Habit of Doctors in Turkey). Türk Tabibler Birliği, 1999.

7. Wang, M.Q.; Fitzhugh, E.C.; Eddy, J.M.; Fu, Q.; Turner, L. Social Influences on Adolescents Smoking Progress-A Longitudinal Analysis. Am. J. Health Behav. 1997, 21 (2), 111-117.

8. Greenlund, K.J.; Johnson, C.C.; Webber, L.S.; Berenson, G.S. Cigarette-Smoking Attitudes and First Use Among Third-Grade Through Sixth-Grade Students-The Bogalusa Heart-Study. Am. J. Public Health 1997, 87 (8), 1345-1348.

9. Wolfson, M.; Forster, J.L.; Claxton, A.J.; Murray, D.M. Adolescent Smokers Provision of Tobacco to Other Adolescents. Am. J. Public Health 1997, 87 (4), 649-651.

10. Miller, P., Family-Structure, Personality, Drinking, Smoking and Illicit Drug-Use-A Study of UK Teenagers. Drug Alcohol Depend. 1997, 45 (1-2), 121-129.

11. Michell, L. Loud, Sad or Bad-Young Peoples Perceptions of Peer Groups and Smoking. Health Educ. Res. 1997, 12 (1), 1-14. 
12. Nojem, G.R.; Batuman, F.; Smith, A.M.; Feuerman, M. Patterns of Smoking Among Inner-City Teenagers-Smoking Has a Pediatric Age-of-Onset. J. Adolescent Health 1997, 20 (3), 226-231.

13. Cowdery, J.E.; Fitzhugh, E.C.; Wang, M.Q. Sociobehavioral Influences on Smoking Initiation of Hispanic Adolescents. J. Adolescent Health 1997, 20 (1), 46-50.

14. Williams, J.G.; Covington, C.J. Predictors of Cigarette-Smoking Among Adolescents. Psychol. Rep. 1997, 80 (2), 481-482.

15. Michell, L.; Amos, A. Girls, Pecking Order and Smoking. Soc. Sci. Med. 1997, 44 (12), 1861-1869.

16. Glendinning, A.; Shucksmith, J.; Hendry, L. Family-Life and Smoking in Adolescence. Soc. Sci. Med. 1997, 44 (1), 93-101.

17. Puikkinen, L. Youthful Smoking and Drinking in a Longitudinal Perspective. J. Youth Adolescence 1983, 12, 253-283.

18. Murray, M.; Kiryluk, S.; Swan, A.V. Relation Between Parents' and Children's Smoking Behavior and Attitudes. J. Epidemiol. Community Health 1985, 39, 169-174.

19. Newcomb, M.D.; McCarthy, W.J.; Bentler, P.M. Cigarette Smoking, Academic Lifestyle, and Social Impact Efficacy: An Eight-year Study from Early Adolescence to Young Adulthood. J. Soc. Psychol. 1989, 19, 251-281.

20. Oygard, L.; Knut-inge, K. Parental and Peer Influences on Smoking Among Young Adults. Addiction 1995, 90 (4), 561-570.

21. Azevado, A.; Machado, A.P.; Barros, H. Tobacco Smoking Among Portuguese High-School-Students. Bull. WHO 1999, 77 (6), 509-514.

22. Abdelrahman, A.I.; Rodriguez, G.; Ryan, J.A.; French, J.E. The Epidemiology of Substance Use Among Middle School StudentsThe Impact of School. Familial. Community and Individual RiskFactors. J. Child Adolescent Subst. Abuse 1998, 8 (1), 55-75.

23. Epstein, J.A.; Williams, C.; Botvin, G.J.; Diaz, T.; IfillWilliams, M. Psychosocial Predictors of Cigarette-Smoking Among Adolescents Living in Public-Housing Developments. Tobacco Control 1999, $8(1), 45-52$.

24. Allison, K.W.; Crawford, I.; Leone, P.E.; Trickett, E.; Perezfebles, A.; Burton, L.M.; Leblanc, R. Adolescent Substance Use Preliminary Examinations of School and Neighborhood Context. Am. J. Comm. Psychol. 1999, 27 (2), 111-141.

25. Canals, J.; Blade, J.; Domenech, E. Smoking and Personality Predictors in Young Spanish People. Personality Individual Diff. 1997, 23 (5), 905-908. 
26. Pederson, L.L.; Koval, J.J.; O'Connor, K. Are Psychological Factors Related to Smoking in Grade-6 Students. Addictive Behav. 1997, 22 (2), 169-181.

27. Patton, D.; Barnes, G.E.; Murray, R.P. A Personality Typology of Smokers. Addictive Behav. 1997, 22 (2), 269-273.

28. Li, X.M.; Fang, X.Y.; Stanton, B. Cigarette-Smoking Among Chinese Adolescents and Its Association with Demographic Characteristics, Social Activities, and Problem Behaviors. Substance Use Misuse 1996, 31 (5), 545-563.

29. Defronzo, J.; Pawlak, R. Gender Differences in the Determinants of Smoking. J. Drug Issues 1993, 24 (3), 507-516.

30. Ferguson, K.J.; Burke, J.A.; Becker, S.L.; Reimers, T.M.; Daughety, V.S.; Pomrehn, P.R. The Recruitment of New Smokers by Adolescents. Health Commun. 1992, 4 (3), 171-181.

31. Lo, S.K.; Blazetemple, D.; Binns, C.W.; Ovenden, C. Adolescent Cigarette Consumption-The Influence of Attitudes and Peer Drug Use. Int. J. Addictions 1993, 28 (14), 1515-1530.

32. Amos, A.; Gray, D.; Currie, C.; Elton, R. Healthy or Druggy-SelfImage, Ideal Image and Smoking-Behaviour Among Young-People. Soc. Sci. Med. 1997, 45 (6), 847-858.

33. Stanton, W.R.; Mahalski, P.A.; Mcgee, R.; Silva, P.A. Reasons for Smoking in Early Adolescence. Addictive Behav. 1993, 18 (3), 321-329.

34. Goldstein, J. Stratification and Smoking: A Search for Class-Based Smoking Lifestyles. J. Drug Educ. 1993, 23 (4), 357-373.

35. Sussman, S.; Brannon, B.R.; Dent, C.W.; Hansen, W.B.; Johnson, C.; Anderson, F.; Brain, R. Relations of Coping Effort, Coping Strategies, Perceived Stress, and Cigarette Smoking Among Adolescents. Int. J. Addictions 1993, 28 (7), 599-612.

36. Nicholson, J.M.; Fergusson, D.M.; Horwood, L.J. Effects on Later Adjustment of Living in a Stepfamily During Childhood and Adolescence. J. Child Psychol. Psychiatry Allied Disciplines 1999, 40 (3), 405-416.

37. Distefan, J.M.; Gilpin, E.A.; Sargent, J.D.; Pierce, J.P. Do Movie Stars Encourage Adolescents to Start Smoking-Evidence from California. Prev. Med. 1999, 28 (1), 1-11.

38. Tyas, S.L.; Pederson, L.L. Psychosocial Factors Related to Adolescent Smoking-A Critical-Review of the Literature. Tobacco Control 1998, 7 (4), 409-420.

39. Bilir, N.; Doğan, B.G.; ve Yıldız A.N. Sigara İçme Konusundaki Davranışlar ve Tutumlar. Hacettepe Halk Sağlı̆̆ Vakfı Yayın No: 7, Ankara, 1997. 
40. Delikaya, H. Ankara Şehir Merkezinde Bulunan Beş Lisedeki Öğrencilerin Sigara ve Alkollü İçki Kullanma Durumları. Yüksek Lisans Tezi. Gazi Üniversitesi, Sağlık Bilimleri Enstitüsü, Ankara, 1999.

41. Sezer, E.; Öztürk, Z.; Bilgin, N.; Açık, Y. Elazığ'da Lise ve Dengi Okul Son Sınıf Öğrencilerinde Sigara İçme Durumu, Fırat University Medical School, unpublished mimeo, 1989.

42. Bağci, T.; Akdăg, F.; Özbek, Z.; Kiliç, F.; Yatsi, P.; ve Bilir, N. Ankara Yenice Bölgesi'ndeki İki İşyerinde Çalışan İşçilerin Sigara İle İlgili Bazı Tutum ve Davranışları. Sağlik ve Sosyal Yardim Vakfi Dergisi 1996, 6 (3), Temmuz-Eylül.

43. Bağci, T.; Bilir, N. Şehirlerarasi Otobüste Çalışan Personelin Sigara İçme Alışkanlığı ve Otobüslerde Sigara İçilmesine Karşı Tutumları. İşçi Sağlığı ve İş Güvenliği Haftası, 4-10 Mayıs, 1997.

44. Cernkovich, S.A.; Giordana, P.C. School Bonding, Race, and Delinquency, Criminology 1992, 30 (2), 261-291.

45. Tobacco Facts. How the world smokes. http://www.tobacco facts.org/ world.html

46. Menard, S. Applied Logistic Regression Analysis; Sage Publications: Thousand Oaks, CA, 1995.

47. Long, J.S. Regression Models for Categorical and Limited Dependent Variables; Sage Publications: Thousand Oaks, CA, 1997.

48. Tabachnick, B.G. and Fidel, L.S., Using Multivariate Statistics, Fourth edition, Boston: Allyn and Bacon, 2001.

49. Tabachnick, B.G. and Fidel, L.S., Using Multivariate Statistics, Fourth edition, Boston: Allyn and Bacon, 2001.

50. Tabachnick, B.G. and Fidel, L.S., Using Multivariate Statistics, Fourth edition, Boston: Allyn and Bacon, 2001.

51. Karavuş, M.; Hayran, O.; Çalı, Ş.; Dalkılıç, A.; Ercan, S.; Gündoğdu, C.; Dengeşik, F.; Lise Öğrencilerinde Stress Düzeyinin Sigara İçme Durumu ile Karılaştırılması, Marmara University, Faculty of Medicine, Unpublished mimeo, 1993.

52. Kıyak, M.; Dağoğlu, T. Lise Öğrencileri Arasında Sigara Kullanımı. İstanbul Halk Sağlığı Bülteni 1988, 11, Year 4.

53. Saltı, A.; Yılmaz, T.; Yorulmaz, F.; Spor, Y. Edirne Merkezinde 5100 Orta-Lise Öğrencisinde Sigara İçme Davranışı ve Speielberger Testi ile Ölçülen Kayg1 Düzeyinin İncelenmesi, İkinci Ulusal Halk Sağlığı Kongresi, İstanbul, 22-25 Mayıs 1990.

54. Güraksın, A.; Ezmeci, T.; Innand1, T.; Keskinler, D.; Vançelik, S.; Tufan, Y. Erzurum İl Merkezinde Ortaokul ve Lise Öğrencilerinde Sigara İçme Prevalansi, Altıncı Ulusal Halk Sağlığı Kongresı, 1994. 
55. Sezer, E. “Elazığ'da Lise ve Dengi Okul Üçüncü Sınıf Öğrencilerinde Sigara İçme Durumu (1989). Fırat Üniversitesi Dergisi 1990, 5 (2).

\section{RESUMEN}

Este estudio investiga los determinantes de fumar entre los estudiantes de secundaria y liceos en Ankara Turquía. El dato fue proporcionado a través de 4800 estudiantes, en el segundo semestre del año 1997-1998. Dicha encuesta se aplicó para investigar la razón del uso entre los jovenes. Además de variables motivos clásicos independientes, hay factores que no se usan frecuentemente en la literatura-tales como: tipo de escuela, relaciones con los vecinos, reliogiosidad familiar y factores que reflejan los antecedentes culturales del estudiante- están incluidos en estos análisis. Los resultados de regresión logistica binomio demuestran que los efectos del tipo de la escuela; la actitud de los fumadores de su ambiente; la presencia de la madastra; el uso de alcohol del padre; hermanas y hermanos fumadores; el uso del alcohol de los estudiantes del medio y la participación en las actividades de arte, son las causas principales que estimulan a los jóvenes.

\section{RÉSUMÉ}

Cet article cherche à déterminer les raisons de fumage entre les lycéens à ankara, Turquie. Les donnés ont été collecté auprès de 4800 lycéens pendant le deuxième semestre de l'année scolaire 1997-1998 et ceci afin de mesurer la prédominance de ce phénomène auprès des jeunes. En plus de variables explicatives classiques, d'autres facteurs rarement utilisés auparavant dans la littérature, ont été introduits telsque le type de lycée, le voisinage, la réligion, ainsi que des facteurs representant la structure culturelle des étudiants. Les résultats d'une regression binomiale logique, indique que les facteurs prédeterminants sont: le type de l'école, l'attitude vis à vis de fumage, la présence d'une belle-mère, l'alcholisme du père, la présence des sœurs ou frères fumeurs, et finalement l'alcolisme de l'élève luimême ainsi que sa participation dans des activités artistiques. 


\section{THE AUTHORS}

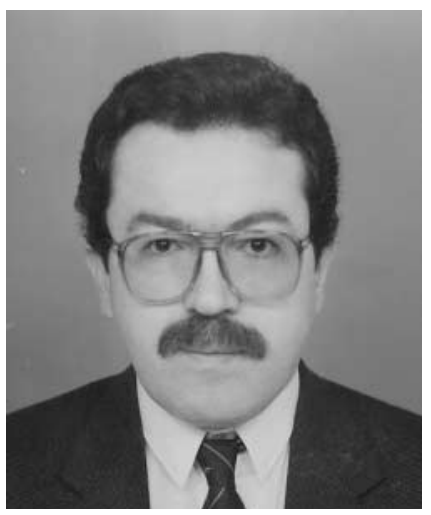

Yusuf Ziya Özcan obtained his Ph.D. from the University of Chicago and is currently an associate professor of sociology at the Middle East Technical University, Ankara, Turkey. He teaches statistics and research methods at both undergraduate and graduate levels in the Department of Sociology. He has published in the areas of social stratification and social mobility, responses rate in surveys, social control and deviance, police, migration, social effects of communication technologies, and political behavior. His recent research interest is substance use and abuse from a comparative perspective.

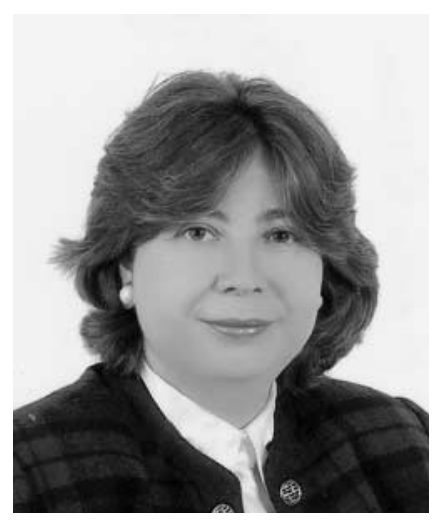

Kivilcim Metin Özcan is an assistant professor of Economics at Bilkent University, Ankara, Turkey. She received her D.Phil from the University of Oxford. Her research interests are macroeconomic modelling and time series analysis of aggregated macroeconomic and financial data. Her work has appeared in Oxford Bulletin of Economics and Statistics, Journal of Business and Economic Statistics, European Journal of Operational Research, Applied Financial Economics, and Empirical Economics. 


\section{Request Permission or Order Reprints Instantly!}

Interested in copying and sharing this article? In most cases, U.S. Copyright Law requires that you get permission from the article's rightsholder before using copyrighted content.

All information and materials found in this article, including but not limited to text, trademarks, patents, logos, graphics and images (the "Materials"), are the copyrighted works and other forms of intellectual property of Marcel Dekker, Inc., or its licensors. All rights not expressly granted are reserved.

Get permission to lawfully reproduce and distribute the Materials or order reprints quickly and painlessly. Simply click on the "Request

Permission/Reprints Here" link below and follow the instructions. Visit the U.S. Copyright Office for information on Fair Use limitations of U.S. copyright law. Please refer to The Association of American Publishers' (AAP) website for guidelines on Fair Use in the Classroom.

The Materials are for your personal use only and cannot be reformatted, reposted, resold or distributed by electronic means or otherwise without permission from Marcel Dekker, Inc. Marcel Dekker, Inc. grants you the limited right to display the Materials only on your personal computer or personal wireless device, and to copy and download single copies of such Materials provided that any copyright, trademark or other notice appearing on such Materials is also retained by, displayed, copied or downloaded as part of the Materials and is not removed or obscured, and provided you do not edit, modify, alter or enhance the Materials. Please refer to our Website User Agreement for more details.

\section{Order now!}

Reprints of this article can also be ordered at http://www.dekker.com/servlet/product/DOI/101081JA120002481 